\title{
Lipase-mediated interesterification of oils and fats for the preparation of bakery and confectionery fats
}

HITHAMANI G ( $\square$ hithamanii@yahoo.co.in )

CSIR-CFTRI https://orcid.org/0000-0002-9532-8521

Yella Sunki Reddy

CSIR-CFTRI

Sakina Khatoon

CSIR-CFTRI

\section{Research Article}

Keywords: Sal fat, palm stearin, palm mid fraction, enzymatic interesterification, bakery and confectionery fats

Posted Date: November 2nd, 2020

DOl: https://doi.org/10.21203/rs.3.rs-67079/v1

License: () (1) This work is licensed under a Creative Commons Attribution 4.0 International License. Read Full License 


\section{Abstract}

Bakery and confectionary fats were prepared by enzymatic interesterification of sal fat with palm stearin and palm mid fraction blends in various ratios. Slip melting point, free fatty acids, fatty acid composition, solid fat content and triglyceride composition were determined. Fatty acid composition revealed that the blends were rich in palmitic (13.9-58.5\%), stearic (7.7$36.7 \%)$ and oleic (25.2-39.9\%) with no trans fatty acids. Blends of sal:PSt (50:50), sal:PMF (50:50 and 25:75) showed high solid fat content at 20 and $25^{\circ} \mathrm{C}$ with short melting range. After interesterification, plasticity of products increased, which were comparable with commercial bakery fat. Some of the blends alone showed short melting profile like cocoa butter. Interesterification produced significant alteration in the triacylglycerol composition of the blends studied. Blends and the interesterified products prepared showed favorable characteristics with no transfats and hence could be used in the place of commercial bakery and confectionary fats.

\section{Introduction}

Most natural oil and fat present, have limited application in their unaltered forms, which is imposed by their particular composition in fatty acids and triacylglycerols. The fatty acids are not randomly distributed in triacylglycerols (TAGs) of natural fats (Martini et al., 2009). The production of some kinds of edible fats requires fat blends that are able to impart plasticity to products such as margarine and shortening. To achieve these properties, fat blends may be modified by chemical or enzymatic interesterification (EIE) which causes modifications in the properties of natural fats. Lipase-catalyzed interesterification is one of the alternative technologies for replacing conventional hydrogenation process to reduce or eliminate trans-fatty acids (Hunter, 2004). Because of the increasing concern about the nutritional impact of trans-fatty acids on health, interesterification has become the main method for the preparation of plastic fat with low or zero trans isomers. Interesterification (EIE), which offers the possibility of manipulating the distribution and composition of fatty acids of TAGs to confer more desirable physicochemical properties on fats, has been widely used as a fat modification process to provide plastic fats of desirable qualities (Norizzah et al., 2004; Chu et al., 2002). In the interesterification reaction, fatty acids remain unaltered, although they are redistributed in the triacylglycerol molecules.

Palm oil is readily available low cost fat and suitable raw material for the production of cocoa butter equivalent (CBE). Preparation of CBE through enzyme catalyzed interesterification has attracted because lipases offer several advantages over other chemical catalysts such as, milder conditions, produces fewer by-products and regio-specificity (Willis et al., 1998). Other advantages are lower energy consumption and better product control, moreover solvent-free reaction has been considered as eco-friendly and economical. While chemical catalysts will randomize all of the fatty acids in triacylglycerol (TAG) mixture, 1, 3specific lipase can incorporate fatty acids into the sn-1, 3-positions without changing the fatty acid residues in the sn-2position (Chang et al., 1990; Daniel et al., 2001; Zarringhalami et al., 2010). Vegetable oils such as mahua, kokum and mango fats, palm oil mid fraction, tea seed oil, and olive oil have been popularly used to prepare CBE by microbial lipases in batch stirred tank reactor (Wisdom et al., 1986). Pinyaphong and Phutrakul (2009) have modified palm oil structure to cocoa butter equivalent by Carica papaya lipase-catalyzed interesterification. However, procedures of lipase-catalyzed interesterification for CBE production have not been practically in industries because microbial lipase is relatively of high cost. Non-specific lipase catalysed interesterification is similar to random chemical interesterification (Boleslaw et al., 2004). Random interesterification was used to prepare low or zero trans plastic fats from blend of liquid oils and hard fats (Martini et al., 2009; Norizzah et al., 2004; Mayamol et al., 2009; Reshma et al., 2008; Farmani et al., 2007; Khatoon, 2000).

Palm oil mid-fraction (liquid/solid state) characteristics are used in the production of confectionary for the replacement of fats such as cocoa butter and margarine. Lipase-catalysed interesterification has been carried out with high oleic sunflower oil (SFO) and fully hydrogenated soybean oil (Adhikari et al., 2009), palm stearin and rice bran oil blends (Reshma et al., 2008), fully hydrogenated soybean, rapeseed and SFO (Farmani et al., 2007), palm stearin-SFO mixtures (Lai et al., 1998), hydrogenated and solid fraction of tea seed oil (Zarringhalami et al., 2010). 
Currently plastic fats are prepared by hydrogenation of vegetable oils and are characterized by high contents of trans fatty acids $(20-50 \%)$ depending on the degree of hydrogenation and the nature of the oils. Trans fatty acids reportedly contribute to several health problems including thrombogenesis that leads to coronary heart disease (Willett et al., 1993). The interesterification provides higher quality plastic fats with satisfactory melting properties and suitable crystallization behavior with little sandy mouth feel.

Plastic fats having varying melting or plastic ranges are used as bakery shortenings, and margarines. Shortenings provide desirable textural properties by lubricating, weakening or shortening food components. Preparation of plastic shortenings from vegetable fats and oils by chemical, enzymatic interesterification and fractionation followed by blending are reported (Wang \& Shahidi, 2011; Zahra \& Alemzadeh, 2011; Khatoon \& Reddy, 2005; Wai et al., 2007; Reddy \& Jeyarani, 2001). Six binary formulations of medium- and long-chain triacylglycerols (MLCT fat) and palm stearin and four ternary formulations of MLCT fat, palm stearin and palm olein were investigated for shortening production (Arifin et al., 2011).

In the present study, preparation of bakery and confectionery fats were attempted using non-traditional and traditional fats/oils viz., sal fat and palm oil fractions. Different fractions of palm oil viz palm stearin (PSt) and palm mid fractions (PMF) were blended with sal fat. Sal fat, a non-traditional fat, is hard, brittle and closely resembles cocoa butter (CB). Palm stearin which is a by-product of palm oil industry and is the hard fraction obtained by palm oil fractionation, was taken to improve tolerance to high temperatures, for crystal morphology and also stability (Chu et al., 2002). Palm mid fraction was obtained by two stage crystallization. Sal fat and plam oil were considered for the experiments because palm oil is rich in POP triglyceride and sal oil with SOS triglyceride, which offers required melting profile to the end products.

\section{Materials And Methods}

\section{Materials}

Crude palm oil was purchased from M/s Palm Tech. India Ltd. (Mysore, Karnataka, India) and Sal (Shorea robusta) fat was procured from M/s K.N. Oil Industries, Mahasamund, M.P., India. Crude sal fat and palm oil were refined and bleached in laboratory as described by Hodgson (1996). Commercial bakery shortenings were procured from M/s Hindustan Lever Ltd., Mumbai, India. Immobilized 1, 3-specific lipase, Lipozyme® RMIM from Rhizomucor miehei, was procured from Novozymes, Bangalore, India. Standards for the estimation of fatty acid methyl esters and triglycerides were procured from Sigma-Aldrich Co., St. Louis, MO, USA. Other solvents and reagents were of analytical grade.

\section{Fractionation and blending}

Crude palm oil was refined, heated to about $50{ }^{\circ} \mathrm{C}$, gradually cooled to $25^{\circ} \mathrm{C}$ with stirring and this temperature was maintained for $4 \mathrm{~h}$. The partially crystallized mass was filtered to separate palmstearin fraction (PSt) and palm mid fraction (PMF). Fractionation yielded 35\% Pst and 40\% PMF was obtained by the removal of $8 \%$ PSt. Palm stearin and palm mid fraction were blended with refined sal fat in various ratios viz., 90:10, 85:15, 80:20, 75:25, 70:30, 65:35, 60:40 and 50:50. The melted blends were held at $100{ }^{\circ} \mathrm{C}$ under vacuum with stirring for $10 \mathrm{~min}$ and homogenized prior interesterification. Promising blends were screened for specific end use.

\section{Interesterification}

Lipozyme RMIM (10\% by weight of oil) was used to carry out the interesterification reaction of purified oil blend (100 g) at $50{ }^{\circ} \mathrm{C}$ with continuous stirring on a magnetic stirrer. The reaction was carried out upto 8 h, the products were drawn at $2,4,6$ and $8 \mathrm{~h}$ intervals either in presence or absence of water or in vacuum. The reaction products were filtered and the enzyme was recovered by washing with hexane. Free fatty acids which were generated during the reaction were neutralized using calculated amount of alkali and each product was filtered using filter aid and finally de-solventized under vacuum.

\section{Physico-chemical analysis of blends and interesterified products}


The fatty acids methyl esters were prepared using methanolic KOH according to AOCS method Ce 2-66 (AOCS, 2002) and analyzed by gas liquid chromatograph (GC-15A, Simadzu Corporation, Kyoto, Japan) equipped with data processor (CR4A, Simadzu Corporation, Kyoto, Japan) and flame ionization detector. The column used was stainless steel ( $3 \mathrm{~m} \times 3.3 \mathrm{~mm})$ coated with 15\% DEGS (Diethylene Glycol Succinate) on Chromosorb W (60-80 mesh). Analysis was carried out under the following conditions; nitrogen flow: $40 \mathrm{~mL} / \mathrm{min}$, column temperature: $180^{\circ} \mathrm{C}$, injector temperature: $220^{\circ} \mathrm{C}$, detector temperature: $230^{\circ} \mathrm{C}$. Standard fatty acid methyl esters were used to identify the fatty acids in the blends.

\section{Slip melting point (SMP)}

Slip melting point of the samples was carried out by open capillary method Cc 4-25 according to standard procedure (AOCS, 2002). The sample was melted and a capillary tube with thin wall and $1 \mathrm{~mm}$ i.d was dipped to fill fat for $10 \mathrm{~mm}$ height. The capillary was touched over a piece of ice to solidify the fat. The capillary was left at refrigerated temperature $\left(10^{\circ} \mathrm{C}\right)$ for 10 $\mathrm{h}$ and at $0{ }^{\circ} \mathrm{C}$ for $1 \mathrm{~h}$. Two capillaries were attached gently to a thermometer using a rubber band and fixed onto a Thiele tube. The side arm of the flask was heated slowly $\left(1{ }^{\circ} \mathrm{C} / \mathrm{min}\right)$ and the temperature at which the fat melts, slips and raises was noted. Triplicate measurements were made and the average value was reported.

\section{Differential Scanning Calorimetry (DSC)}

Melting characteristics of the samples were determined using a Mettler differential scanning calorimeter (Zurich, Switzerland, DSC-30). Indium was used to calibrate the heat flow of the instrument. All the samples were heated to $60^{\circ} \mathrm{C}$ to ensure homogeneity and to destroy all crystal nuclei. Molten sample $(15 \mathrm{mg})$ was accurately weighed into standard aluminum crucible and cover crimped in place. An empty aluminum crucible with pierced lid served as reference. The samples were stabilized by keeping at $0{ }^{\circ} \mathrm{C}$ for $90 \mathrm{~min}, 26^{\circ} \mathrm{C}$ for $40 \mathrm{~h}$ and $0{ }^{\circ} \mathrm{C}$ for $90 \mathrm{~min}$ prior to introduction into DSC cell (IUPAC, 1987). Thermograms were recorded by heating the sample at the rate of $2{ }^{\circ} \mathrm{C} / \mathrm{min}$ from -10 to $60{ }^{\circ} \mathrm{C}$. The percentage of liquid at various temperatures was recorded directly using data processor TC-10A and STARe program. The solid fat content (SFC) was calculated from the percentage of liquid.

\section{Triglyceride composition}

Triacylglycerol (TG) composition was determined by Simadzu LC-10A high performance liquid chromatograph (HPLC) equipped with Software Class AVP (Simadzu Corp., Tokyo, Japan) and refractive index detector as given by Haryati et al., (1999). Column used was C-18 (ODS, $25 \mathrm{~cm} \times 4.6 \mathrm{~mm}$ ) maintained at $40^{\circ} \mathrm{C}$. The mobile phase consisted of acetone and acetonitrile $(63.5: 36.5, \mathrm{v} / \mathrm{v})$ at a flow rate of $1 \mathrm{ml} / \mathrm{min}$. Peaks were identified comparing with standards and reported as trisaturated $\left(\mathrm{GS}_{3}\right)$, monounsaturated $\left(\mathrm{GS}_{2} \mathrm{U}\right)$, diunsaturated $\left(\mathrm{GSU}_{2}\right)$ and triunsaturated $\left(\mathrm{GU}_{3}\right)$ triglycerides.

\section{Statistical data analysis}

Experimental results were carried out in triplicates, and the results are shown as mean value and standard deviation. Duncan's multiple range test (DMRT) was applied to differentiate the solid fat content and triglycerides species among the means of different samples at a probability $(P)$ of $\leq 0.05$ (Duncan, 1995).

\section{Results And Discussion}

\section{Effect of enzymatic interesterification (EIE) on physico-chemical properties of sal blends with palm stearin and palm mid fraction}

\section{Slip melting point (SMP)}

Blends containing high sal fat percentage (85 to $60 \%$ ) showed increase in SMP and those of high palm stearin blends (60 and $80 \%$ ) showed decrease in SMP after interesterification and also the effect depended on time of reaction. SMP 
decreased in the blends with equal proportion of sal and PSt and increased with the interesterification time. Sal:PMF blends followed the same trend as sal:PSt. It is known that SMP is only an indication of final melting of the sample and does not show the entire melting profiles, which is required to assess the suitability of the sample for any end product.

\section{Free fatty acid (FFA)}

It was observed that there was a sudden increase in FFA during interesterification for $2 \mathrm{~h}$ and thereafter increase was not significant (Fig. 1a). FFA formation was less in the products (Fig. 1b) prepared without added moisture (increased from 0 to $5 \%$ in $2 \mathrm{~h}$ ) as compared to those with added moisture (increased from 0 to $16 \%$ in $2 \mathrm{~h}$ ). FFA formation under vacuum was comparatively less than that with the solvent.

\section{Fatty acid composition}

All the blends of sal fat and PSt/PMF were rich in palmitic (13.9- 58.5\%), stearic (7.7- 36.7\%) and oleic acids (25.247.1\%). Fatty acid composition varied depending on the ratio and yield percentage of fractions used for blending and all did not contain any trans fatty acids (Table 1 ).

Palm stearin is known to promote the formation of desirable solid fat having b' crystal when it was interesterified with vegetable oils resulting in smooth textured products (Ming et al., 1999; Ghotra et al., 2002). The $\beta^{\prime}$-crystal form is more stable in shortenings with higher palmitic acid contents (Jeyarani \& Reddy, 2003). Due to high palmitic acid content these samples impart a desirable smooth consistency required for bakery shortenings. The fatty acid composition of the interesterified products is not shown as interesterification did not alter the fatty acid composition and only alters the distribution of fatty acid on glycerol backbone (Lida et al., 2007; Allen, 1996).

\section{Solid fat content (SFC)}

The SFC of fats is responsible for functional characteristics of plastic fats, including their general appearance, ease of packing, spreadability, oil exudation and organoleptic properties. SFC at $20^{\circ} \mathrm{C}$ and $30{ }^{\circ} \mathrm{C}$ in particular are important in margarine manufacture, and must be as low as possible to prevent a sandy and coarse texture of the margarine (Osorioa et al., 2006). The plasticity or SFC varied depending on the proportion of palm stearin. Blends with higher proportions of palm stearin were harder than those with lower proportions. Blends containing sal and PSt showed increased plasticity with lower SFC at ambient temperature after interesterification (Table 2). Aquedo et al., (2008) reported that enzymatic interesterification (EIE) of anhydrous milk fat with linseed and rapeseed oil in the ratio 70/30 and 60/40 resulted in plastic fats with decreased SFC.

The blends of sal: PSt (75-85 to 15-25) and sal with PMF (50-75 sal) showed short melting range with high SFI at ambient temperature with no solids at body temperature like those of cocoa butter (CB) (Table $\mathbf{2}$ \& Fig. 2a \& b). The blends with higher percentage of PSt showed higher SFC at and above $35^{\circ} \mathrm{C}$. Hence, these blends of PSt and PMF with sal alone could be used as cocoa butter extenders.

On interesterification, these blends of sal with PSt or PMF changed into long melting range with less SFC at $20-25^{\circ} \mathrm{C}$ and extending solids at and above $40{ }^{\circ} \mathrm{C}$ (Table 2). Similar results were observed by De Martini et al., (2012) with blends of palm stearin, coconut and canola oil. The interesterified blends of sal:PSt (75:25/8h) and sal:PMF (50:50/6h) showed long melting range like plastic fats and are similar to those of commercial hydrogenated fat used for bakery products (Fig. 2a \& b).

The interesterified products of sal:PSt (60:40/2h) and sal:PMF (75:25 \& 70:30/6h, 40:60/2h) showed soft consistency and the melting profiles or SFC are similar to those of commercial butter.

\section{Triglyceride composition}

The molecular triacylglycerol (TAG) species profile is the key for understanding several physical properties of a given oil or fat. According to the laws of probability, the interesterification reaction results in complete fatty acid randomization among all triacylglycerols present (Rousseau \& Marangoni, 2002). 
The Interesterification produced significant alteration in the TAG composition of the blends. Palm stearin and sal blends (50:50) showed increase in trisaturated glycerides $\left(\mathrm{GS}_{3}\right)$ and decrease in monosaturated diunsaturated glycerides $\left(\mathrm{GSU}_{2}\right)$ and hence SFC at $35^{\circ} \mathrm{C}$ and above increased after interesterification. The $\mathrm{GS}_{3}$ and $\mathrm{GSU}_{2}$ triglycerides increased in $65: 35$ blends after EIE and resulted in increased SFI at $37^{\circ} \mathrm{C}$ and above (Table 3). Significant difference was observed in the slip melting point of Sal:PSt (75:25) after interesterification, where $\mathrm{GS}_{3}$ increased, while disaturated monounsaturated glycerides $\left(\mathrm{GS}_{2} \mathrm{U}\right)$ decreased compared to those in the blend. Results showed that after interesterification for different time intervals tri-saturated glycerides were reduced and di-unsaturated increased in Sal:PSt (20:80) blend (Table 4). The observed physical properties like SMP and SFC are due to changes in TAG composition after interesterification.

In case of sal and PMF blends after $2 \mathrm{~h}$ reaction, the product did not show any difference in $\mathrm{GU}_{3}$ triglycerides compared to parent blend and $\mathrm{GS}_{3}, \mathrm{GSU}_{2}$ not showed any significant increase, while $\mathrm{GS}_{2} \mathrm{U}$ reduced (Table 5). Due to changes in triglyceride composition, SFC reduced at $20-25^{\circ} \mathrm{C}$ in all these blends.

\section{Conclusion}

Trans free bakery and confectionary fats were prepared by enzymatic interesterification of blends of sal with PSt and PMF. Palm stearin and sal fat, a non-traditional fat, used in the present study are of low cost, at the same time they offer technical advantages and improved quality with the added health benefit. Blends prepared with sal and palm oil fractions (PSt and PMF) could be used as cocoa butter replacers even in tropical climatic conditions. Interesterification of sal blends with PSt/PMF produced products with desirable low SFC, long plasticity comparable with that of commercial butter and can also be used as margarine base.

\section{Declarations}

\section{Acknowledgement}

Authors are thankful to The Ministry of Food and Civil Supplies, Govt. of India for financial support.

\section{Conflict of interest}

The authors declare no conflict of interest.

\section{References}

Adhikari, D., Li, P. \& Shin, J. A. (2009). Lipase-catalysed interesterification of high oleic sunflower oil and fully hydrogenated soybean oil comparison of batch and continuous reactor for production of zero trans shortening fats. LebensmittelWissenschaft \& Technologie - Food Science and Technology, 43, 458-464.

Aguedo, M., Hanon, E., Danthine, S., Paquot, M., Lognay, G., Thomas, A., Vandenbol, M., Thonart, P., Wathelet, J. P. \& Blecker, C. (2008). Enrichment of anhydrous milk fat in polyunsaturated fatty acid residues from linseed and rapeseed oils through enzymatic interesterification. Journal of Agricultural Food Chemistrty, 56, 1757-1765.

Allen, D. A. (1996). Interesterification- A vital tool for the future?. Lipid technology, 8, 11-15.

AOCS. (2002). Methods Ce 2-66; Cc 4-25. Official methods and recommended practices of the American Oil Chemists' Society, $5^{\text {th }}$ edn. Champaign, IL: AOCS Press.

Arifin, N., Cheong, L. Z., Koh, S. P., Long, K., Tan, C. P., Yusoff, M. S. A., Aini, I. N., Lo, S. K. \& Lai, O. M. (2011). Physicochemical properties and sensory attributes of medium and long-chain triacylglycerols (MLCT) enriched bakery shortening. Food 
Boleslaw, K., Tarnowska, K., Gruczynska, E. \& Bekas, W. (2004). Chemical and enzymatic interesterification of beef tallow and rape seed oil equal-weight blend. European Journal of Lipid Science and Technology, 106, 655-664.

Chang, M. K., Abraham, G. \& John, V. T. (1990). Production of cocoa butter like fat from interesterification of vegetable oils. Journal of the American Oil Chemists' Society, 67, 832-834.

Chu, B. S., Ghazali, H. M., Lai, O. M., Cheman, Y. B. \& Yusof, S. (2002). Physical and chemical properties of a lipasetransesterified palm stearin/palm kernel olein blend and its isopropanol-solid and high melting triacylglycerol fractions. Food Chemistry, 76, 155-164.

Daniel, U., Markovits, A. \& Erazo, S. (2001). Cocoa butter equivalent through enzymatic interesterification of palm oil mid fraction. Process Biochemistry, 36, 933-939.

De Martini Soares, F. A. S., da Silva, R. C., Guimaraes da Silva, K. C., Lourenc,o, M. B., Soares, D. F. \& Gioielli, L. A. (2009). Effects of chemical interesterification on physicochemical properties of blends of palm stearin and palm olein. Food Research International, 42, 1287-1294.

De Martini Soares, F. A. S., da Silva, R. C., Hazzan, M., A. Capacla, I. R., Viccola, E. R., Maruyama, J. M. \& Gioielli, L. (2012). Chemical interesterification of blends of palm stearin, coconut oil, and canola oil: Physicochemical properties, Journal of Agricultural Food Chemistrty, 60(6), 1461-1469.

Duncan, D. B. (1955). Multiple range and multiple F tests. Biometrics, 11, 1-42.

Farmani, J., Hamedi, M., Safari, M. \& Madadlou, A. (2007). Trans free Iranian vanaspati through enzymatic and chemical transesterification of triple blends of fully hydrogenated soybean, rapeseed and sunflower oils. Food Chemistry, 102, 827-833.

Ghotra B. S., Dyal S. D. \& Narine S. S. (2002). Lipid shortenings: a review, Food Research International, 35, 1015-1048.

Haryati, T., Che, Man, Y. B., Jinap, S. \& Ghazali, H. M. (1999). Optimization of chemical transesterification of palm oil using surface methodology. Journal of Food Lipids, 6, 91-106.

Hodgson, B. F. (1996). Refining and bleaching. In: Bailey's Industrial Oils and Fats Products. Eds. Y.H. Hui, Interscience publication, Johan Wiley and Sons Inc., New York (USA), Vol. 4, pp.172-176, 201-204.

Hunter, J. E.(2004). Alternatives to trans fatty acids in foods. Inform, 15, 510-512.

IUPAC (International Union of Pure and Applied Chemistry). 1987. Standard methods for the analysis of oils and fats and derivatives, $7^{\text {th }}$ edn. Paquot, C., Hautfenne, A., Eds.; Blackwell Scientific Publications, London.

Jeyarani, T. \& Yella Reddy, S. (2003). Preparation of plastic fats with zero trans fatty acids from palm oil. Journal of the American Oil Chemists' Society, 80, 1107-1113.

Khatoon, S. \& Reddy, S. Y. (2005). Plastic fats with zero trans fatty acid by interesterification of mango, mahua and palm oils. European Journal Lipid Science Technology, 107, 786-791.

Khatoon, S. (2000). Semisolid fat by interesterification of red palm oil with other vegetable oils. Journal of Food Lipids, 7, 8393.

Lai, O. M., Ghazali, H. M. \& Chong, C. L. (1998). Effect of enzymatic transesterification on the melting points of palm stearinsunflower oil mixtures. Journal of the American Oil Chemists' Society, 75, 881-886. 
Lida, H. M. D. N., Kalyana, S. \& Nor, A. I. (2007). Effect of chemical interesterification on triacylglycerol and solid fat contents of palm stearin, sunflower oil and palm kernel olein blends. European Journal Lipid Science Technology, 109, 147-156.

Mayamol, P.N., Balachandran, C., Samuel, T., Sundaresan, A. \& Arumughan, C. (2009). Zero trans shortening using rice bran oil, palm oil and palm stearin through interesterification at pilot scale. International Journal of Food Science and Technology, 44, $18-28$.

Ming, L. O., Ghazali, H. M. \& Let, C. C. (1999). Use of enzymatic transesterified palm stearin-sunflower oil blends in the preparation of table margarine formulation. Food Chemistry, 64, 83-88.

Norizzah, A. R., Chong, C. L., Cheow, C. S. \& Zaliha, O. (2004). Effects of chemical interesterification on physicochemical properties of palm stearin and palm kernel olein blends. Food Chemistry, 86, 229- 235.

Osórioa, N. M., Da Fonseca, M. M. R. \& Ferreira-Dias, S. (2006). Operational stability of Thermomyces lanuginose lipase during interesterification of fat in continuous packed-bed reactors. European Journal Lipid Science Technology,108, 545-553.

Pinyaphong, P.\& Phutrakul, S. (2009). Modification of palm oil structure to cocoa butter equivalent by Carica papaya lipasecatalyzed interesterification. World Academy of Science, Engineering and Technology, 54, 536-540.

Reddy, S. Y. \& Jeyarani, T. (2001). Trans free bakery shortenings from mango kernel and mahua fats by fractionation and blending. Journal of the American Oil Chemists' Society, 78, 635-640.

Reshma, M.V., Saritha, S. S., Balachandran, C. \& Arumughan, C. (2008). Lipase catalyzed interesterification of palm stearin and rice bran oil blends for preparation of zero trans shortening with bioactive phytochemicals. Bioresource Technology, 99, 50115019.

Rousseau, D. \& Marangoni, A. G. (2002). The effects of interesterification on the physical properties of fats. In: Physical Properties of Lipids, Marangoni, A. G.; Narine, S.S. Eds., CRC Press, Boca Raton, FL, pp. 479-565.

Wai, L. S., Cheah, K. Y. \& Tang, W. L. (2007). Physical properties of lipase catalyzed interesterification of palm stearin with canola oil blends. European Journal Lipid Science Technology, 109, 97-106.

Wang, J. \& Shahidi, F. (2011). Effect of Enzymatic Randomization on Positional Distribution and Stability of Seal Blubber and Menhaden Oils. Journal of Agricultural Food Chemistry, 59, 4232- 4237.

Willett, W. C., Stampfer, M. J., Manson, J. E., Colditz, G. A., Speizer, F. E., Rosner, B. A., Sampson, L. A. \& Hennenkens, C. H. (1993). Intake of trans Fatty Acids and Risk of Coronary Heart Disease Among Women. Lancet, 341, 581-585.

Willis, W. M., Lencki, R. W. \& Marangoni, A. G. (1998). Lipid modification strategies in the production of nutraceutical fats and oils. CRC Rev. Food Science and Nutrition, 38, 639-674.

Wisdom, R. A., Dunnil P. \& Lilly, M. D. (1986). Enzymatic interesterification of fats: laboratory and pilot-scale studies with immobilized lipase from Rhizopus arrhizus. Biotechnology and Bioengineering, 29, 1081-1085.

Zahra, K. Y. \& Alemzadeh, I. (2011). Improvement of palm oil and sunflower oil blends by enzymatic Interesterification. International Journal of Food Science and Technology, 46, 1093-1099.

Zarringhalami, S., Sahari, M. A., Barzegar, M. \& Hamidi-Esfehani, Z. (2010). Enzymatically modified tea seed oil as cocoa butter replacer in dark chocolate. International Journal of Food Science and Technology, 45, 540-545.

\section{Tables}

Table 1 Fatty acid composition of blends 


\begin{tabular}{|c|c|c|c|c|c|c|c|c|}
\hline \multirow[t]{2}{*}{ Sample } & \multirow[t]{2}{*}{ Ratio } & \multicolumn{7}{|c|}{ Fatty acid composition (Relative \%) } \\
\hline & & C12:0 & C14:0 & C16:0 & C18:0 & $\mathrm{C} 20: 0$ & C18:1 & C18:2 \\
\hline Sal fat & - & $\overline{n d}$ & nd & $6.8 \pm 0.1$ & $35.6 \pm 0.3$ & $7.3 \pm 0.1$ & $47.1 \pm 0.3$ & $2.6 \pm 0.0$ \\
\hline Cocoabutter & - & $1.8 \pm 0.1$ & $0.8 \pm 0.1$ & $26.8 \pm 0.2$ & $32.6 \pm 0.5$ & $1.8 \pm 0.2$ & $33.7 \pm 0.1$ & $2.3 \pm 0.1$ \\
\hline \multirow[t]{7}{*}{ Sal: PSt } & $85: 15$ & $2.8 \pm 0.3$ & $2.2 \pm 0.1$ & $13.9 \pm 0.1$ & $36.7 \pm 0.4$ & $5.4 \pm 0.1$ & $35.4 \pm 0.2$ & $3.2 \pm 0.0$ \\
\hline & $80: 20$ & nd & $0.4 \pm 0.2$ & $17.1 \pm 0.3$ & $34.8 \pm 0.2$ & $5.2 \pm 0.0$ & $39.9 \pm 0.3$ & $2.4 \pm 0.2$ \\
\hline & $75: 25$ & $2.6 \pm 0.0$ & $2.8 \pm 0.3$ & $20.0 \pm 0.5$ & $32.5 \pm 0.1$ & $2.8 \pm 0.1$ & $35.2 \pm 0.1$ & $3.5 \pm 0.1$ \\
\hline & $70: 30$ & $1.0 \pm 0.0$ & $1.0 \pm 0.1$ & $25.4 \pm 0.3$ & $28.7 \pm 0.0$ & $3.4 \pm 0.2$ & $37.2 \pm 0.2$ & $3.2 \pm 0.2$ \\
\hline & $65: 35$ & $0.9 \pm 0.1$ & $1.0 \pm 0.0$ & $27.3 \pm 0.2$ & $27.9 \pm 0.0$ & $3.6 \pm 0.1$ & $36.0 \pm 0.4$ & $3.3 \pm 0.1$ \\
\hline & $60: 40$ & nd & $0.6 \pm 0.1$ & $28.8 \pm 0.2$ & $25.3 \pm 0.1$ & $3.4 \pm 0.3$ & $38.5 \pm 0.2$ & $3.5 \pm 0.2$ \\
\hline & $50: 50$ & $1.6 \pm 0.0$ & $1.6 \pm 0.1$ & $34.1 \pm 0.0$ & $26.6 \pm 0.2$ & $2.3 \pm 0.0$ & $32.0 \pm 0.1$ & $1.7 \pm 0.0$ \\
\hline \multirow[t]{9}{*}{ Sal:PMF } & $80: 20$ & nd & $0.2 \pm 0.0$ & $17.4 \pm 0.1$ & $34.8 \pm 0.1$ & $5.3 \pm 0.2$ & $39.7 \pm 0.2$ & $2.3 \pm 0.1$ \\
\hline & $75: 25$ & nd & $0.4 \pm 0.1$ & $22.7 \pm 0.2$ & $32.6 \pm 0.2$ & $6.1 \pm 0.1$ & $36.0 \pm 0.1$ & $2.2 \pm 01$ \\
\hline & $70: 30$ & nd & $0.4 \pm 0.0$ & $24.4 \pm 0.1$ & $34.4 \pm 0.1$ & $5.3 \pm 0.1$ & $33.2 \pm 0.1$ & $2.3 \pm 0.2$ \\
\hline & $60: 40$ & nd & $0.6 \pm 0.1$ & $26.6 \pm 0.3$ & $25.9 \pm 0.1$ & $3.9 \pm 0.2$ & $39.9 \pm 0.1$ & $3.2 \pm 0.1$ \\
\hline & $50: 50$ & $1.7 \pm 0.1$ & $1.7 \pm 0.2$ & $31.7 \pm 0.1$ & $22.2 \pm 0.2$ & $1.5 \pm 0.0$ & $35.9 \pm 0.1$ & $5.1 \pm 0.0$ \\
\hline & $40: 60$ & nd & $0.7 \pm 0.1$ & $35.8 \pm 0.1$ & $19.2 \pm 0.1$ & $2.6 \pm 0.2$ & $38.9 \pm 0.5$ & $2.8 \pm 0.3$ \\
\hline & $30: 70$ & $0.5 \pm 0.3$ & $1.1 \pm 0.0$ & $40.3 \pm 0.2$ & $17.7 \pm 0.2$ & $2.3 \pm 0.1$ & $34.7 \pm 0.1$ & $3.3 \pm .2$ \\
\hline & $25: 75$ & $0.4 \pm 0.0$ & $1.0 \pm 0.4$ & $42.2 \pm 0.1$ & $16.5 \pm 0.0$ & $2.1 \pm 0.2$ & $33.5 \pm 0.3$ & $4.1 \pm 0.1$ \\
\hline & $10: 90$ & $3.6 \pm 0.2$ & $2.6 \pm 0.0$ & $58.5 \pm 0.4$ & $7.7 \pm 0.35$ & $0.6 \pm 0.0$ & $25.2 \pm 0.1$ & $1.7 \pm 0.1$ \\
\hline
\end{tabular}

Pst- Palm stearin, PMF-Palm mid fraction, nd-Not detected

Values are mean \pm SD of triplicate values

Table 2 Solid fat content of blends and interesterified products at different temperatures 


\begin{tabular}{|c|c|c|c|c|c|c|c|c|}
\hline \multirow[b]{2}{*}{ Blend } & \multicolumn{8}{|c|}{ Temperature $\left({ }^{\circ} \mathrm{C}\right)$} \\
\hline & 20 & 25 & 30 & 32.5 & 35 & 37.5 & 40 & 42.5 \\
\hline $\begin{array}{l}\text { Sal:PSt, } \\
80: 20\end{array}$ & $79.4 \pm 0.3^{\circ}$ & $74.6 \pm 0.2^{\mathrm{n}}$ & $57.6 \pm 0.1^{\circ}$ & $33.5 \pm 0.1^{\mathrm{k}}$ & $6 \pm 0.1^{\mathrm{b}}$ & $1 \pm 0.0^{\mathrm{a}}$ & 0 & 0 \\
\hline $75: 25$ & $94 \pm 0.4^{\mathrm{q}}$ & $88.5 \pm 0.4^{\mathrm{r}}$ & $65.4 \pm 0.1^{\mathrm{q}}$ & $28.5 \pm 0.1^{\mathrm{g}}$ & $3 \pm 0.0^{\mathrm{a}}$ & $1 \pm 0.1^{\mathrm{a}}$ & 0 & 0 \\
\hline $70: 30$ & $97.0 \pm 0.2^{r}$ & $85.0 \pm 0.1^{\mathrm{p}}$ & $71.0 \pm 0.1^{\mathrm{r}}$ & $52.0 \pm 0.1^{\mathrm{r}}$ & $11.4 \pm .01^{\mathrm{e}}$ & $3.0 \pm 0.1^{\mathrm{c}}$ & $1.0 \pm 0.0^{\mathrm{c}}$ & 0 \\
\hline $65: 35$ & $97.0 \pm 0.1^{\mathrm{r}}$ & $86.0 \pm 0.1^{\mathrm{q}}$ & $73.0 \pm 0.2^{\mathrm{s}}$ & $49.0 \pm 0.2^{q}$ & $13.0 \pm 0.1^{\mathrm{f}}$ & $5.0 \pm 0.1^{\mathrm{f}}$ & $2.0 \pm 0.1^{\mathrm{d}}$ & 0 \\
\hline $60: 40$ & $76.0 \pm 0.0^{\mathrm{m}}$ & $70.0 \pm 0.0^{\mathrm{k}}$ & $52.0 \pm 0.1^{\mathrm{m}}$ & $30.0 \pm 0.1^{\mathrm{i}}$ & $14.0 \pm 0.1^{\mathrm{g}}$ & $6.0 \pm 0.2^{g}$ & 0 & 0 \\
\hline $50: 50$ & $93.0 \pm 0.1^{\mathrm{p}}$ & $75.0 \pm 0.1^{\mathrm{n}}$ & $65.0 \pm 0.1^{\mathrm{p}}$ & $33.0 \pm 0.1^{j}$ & $20.0 \pm 0.1^{\mathrm{i}}$ & $14 \pm 0.1^{\mathrm{m}}$ & $8 \pm 0.1^{\mathrm{fg}}$ & $4 \pm 0.1^{\mathrm{d}}$ \\
\hline $\begin{array}{l}\text { Sal:PMF, } \\
75: 25\end{array}$ & $77.5 \pm 0.1^{\mathrm{n}}$ & $72.6 \pm 0.1^{\mathrm{m}}$ & $57.3 \pm 0.2^{\mathrm{n}}$ & $36.6 \pm 0.1^{1}$ & $10.3 \pm 0.3^{\mathrm{d}}$ & $1.0 \pm 0.1^{\mathrm{a}}$ & 0 & 0 \\
\hline $70: 30$ & $77.6 \pm 0.1^{\mathrm{n}}$ & $71.3 \pm 0.1^{1}$ & $52.0 \pm 0.1^{\mathrm{m}}$ & $39.0 \pm 0.2^{\mathrm{m}}$ & $13.0 \pm 0.2^{\mathrm{f}}$ & $2.0 \pm 0.1^{b}$ & $0.5 \pm 0.1^{a}$ & 0 \\
\hline $60: 40$ & $71.0 \pm 0.0^{1}$ & $64.6 \pm 0.1^{\mathrm{j}}$ & $44.0 \pm 0.2^{\mathrm{h}}$ & $25.0 \pm 0.1^{\mathrm{f}}$ & $15.0 \pm 0.1^{\mathrm{h}}$ & $7.0 \pm 0.1^{\mathrm{h}}$ & $1 \pm 0.0^{\mathrm{c}}$ & 0 \\
\hline $50: 50$ & $94.0 \pm 0.2^{q}$ & $84.0 \pm 0.1^{\circ}$ & $46.0 \pm 0.1^{j}$ & $15.0 \pm 0.1^{\mathrm{a}}$ & $9.0 \pm 0.1^{\mathrm{c}}$ & $4.0 \pm 0.1^{\mathrm{e}}$ & 0 & 0 \\
\hline $40: 60$ & $67.6 \pm 0.1^{\mathrm{k}}$ & $61.5 \pm 0.2^{\mathrm{h}}$ & $43.4 \pm 0.2^{\mathrm{g}}$ & $24.5 \pm 0.1^{\mathrm{e}}$ & $14.5 \pm 0.1^{\mathrm{g}}$ & $7.7 \pm 0.2^{\mathrm{i}}$ & $2 \pm 0.1^{\mathrm{d}}$ & 0 \\
\hline $\begin{array}{l}\text { Products/Time } \\
\text { (h) }\end{array}$ & & & & & & & & \\
\hline $\begin{array}{l}\text { Sal:PSt, } \\
70: 30 \text { (6) }\end{array}$ & $60.0 \pm 0.1^{\mathrm{h}}$ & $53.0 \pm 0.1^{\mathrm{g}}$ & $51.0 \pm 0.1^{1}$ & $48.0 \pm 0.1^{p}$ & $39.0 \pm 0.2^{\mathrm{m}}$ & $27.0 \pm 0.1^{p}$ & $13.0 \pm 0.2^{h}$ & $5.0 \pm 0.1^{\mathrm{e}}$ \\
\hline $65: 35(6)$ & $62.0 \pm 0.1^{\mathrm{i}}$ & $53.0 \pm 0.1^{\mathrm{g}}$ & $48.0 \pm 0.3^{\mathrm{k}}$ & $45.0 \pm 0.1^{\circ}$ & $35.0 \pm 0.1^{1}$ & $23.0 \pm 0.3^{\circ}$ & $10.0 \pm 0.1^{\mathrm{gh}}$ & $5.0 \pm 0.1^{\mathrm{e}}$ \\
\hline $60: 40(2)$ & $33.0 \pm 0.1^{\mathrm{d}}$ & $30.0 \pm 0.0^{\mathrm{d}}$ & $26.0 \pm 0.0^{\mathrm{d}}$ & $21.0 \pm 0.2^{\mathrm{d}}$ & $14.0 \pm 0.1^{\mathrm{g}}$ & $6.0 \pm 0.1^{\mathrm{g}}$ & $2.0 \pm 0.1^{\mathrm{d}}$ & 0 \\
\hline $60: 40(4)$ & $45.0 \pm 0.2^{\mathrm{e}}$ & $45.0 \pm 0.1^{\mathrm{e}}$ & $45.0 \pm 0.1^{\mathrm{i}}$ & $40.0 \pm 0.1^{\mathrm{n}}$ & $32.0 \pm 0.1$ & $19.0 \pm 0.1^{\mathrm{n}}$ & $9.0 \pm 0.1^{\mathrm{g}}$ & $4.0 \pm 0.1^{\mathrm{d}}$ \\
\hline $50: 50(6)$ & $50.0 \pm 0.1^{\mathrm{g}}$ & $47.0 \pm 0.3^{\mathrm{f}}$ & $41.0 \pm 0.1^{\mathrm{f}}$ & $33.0 \pm 0.1^{j}$ & $22.0 \pm 0.6^{j}$ & $8.0 \pm 0.0^{\mathrm{i}}$ & $1.0 \pm 0.0^{\mathrm{C}}$ & 0 \\
\hline $\begin{array}{l}\text { Sal:PMF, } \\
75: 25 \text { (6) }\end{array}$ & $24.7 \pm 0.1^{\mathrm{a}}$ & $23.0 \pm 0.2^{\mathrm{a}}$ & $21.5 \pm 0.4^{\mathrm{a}}$ & $18.5 \pm 0.1^{b}$ & $14.0 \pm 0.2^{\mathrm{g}}$ & $8.5 \pm 0.1^{j}$ & $5.0 \pm 0.1^{\mathrm{def}}$ & $3.0 \pm 0.0^{\mathrm{C}}$ \\
\hline $70: 30$ (6) & $29.0 \pm 0.1^{b}$ & $27.0 \pm 0.1^{\mathrm{b}}$ & $24.0 \pm 0.2^{\mathrm{c}}$ & $20.0 \pm .1^{\mathrm{c}}$ & $15.0 \pm 0.1^{\mathrm{h}}$ & $9.5 \pm 0.1^{\mathrm{k}}$ & $4.0 \pm 0.1^{\mathrm{de}}$ & $2.0 \pm 0.1^{\mathrm{b}}$ \\
\hline $50: 50(6)$ & $66.0 \pm 0.1^{j}$ & $63.0 \pm 0.1^{\mathrm{i}}$ & $51.0 \pm 0.1^{1}$ & $40.0 \pm 0.1^{\mathrm{n}}$ & $24.0 \pm 0.2^{\mathrm{k}}$ & $11.0 \pm 0.2^{1}$ & $7.0 \pm 0.1^{\text {efg }}$ & $3.0 \pm 0.2^{\mathrm{c}}$ \\
\hline $40: 60(2)$ & $32.4 \pm 0.1^{\mathrm{c}}$ & $28.0 \pm 0.3^{\mathrm{c}}$ & $23.4 \pm 0.1^{b}$ & $18.5 \pm 0.1^{b}$ & $11.5 \pm 0.1^{\mathrm{e}}$ & $3.4 \pm 0.1^{\mathrm{d}}$ & $0.7 \pm 0.1^{b}$ & 0 \\
\hline $\begin{array}{l}\text { Commercial } \\
\text { fat- } 2\end{array}$ & $48.5 \pm 0.1^{\mathrm{f}}$ & $45 \pm 0.1^{\mathrm{e}}$ & $37 \pm 0.0^{\mathrm{e}}$ & $29 \pm 0.1^{\mathrm{h}}$ & $27 \pm 0.1$ & $19 \pm 0.1^{n}$ & $8 \pm 0.1^{\mathrm{fg}}$ & $0.4 \pm 0.1^{\mathrm{a}}$ \\
\hline $\begin{array}{l}\text { Hydrogenated } \\
\text { fat }\end{array}$ & $50-65$ & $40-60$ & $35-50$ & $30-45$ & $25-45$ & $15-30$ & $3-8$ & 0 \\
\hline
\end{tabular}

Pst- Palm stearin, PMF-Palm mid fraction

Values are mean \pm SD of triplicate values; Values not having similar superscripts in the same column are significantly ( $P \leq$ 0.05) different.

Table 3 Triglyceride composition of sal and fractions of palm oil blends and interesterified products 


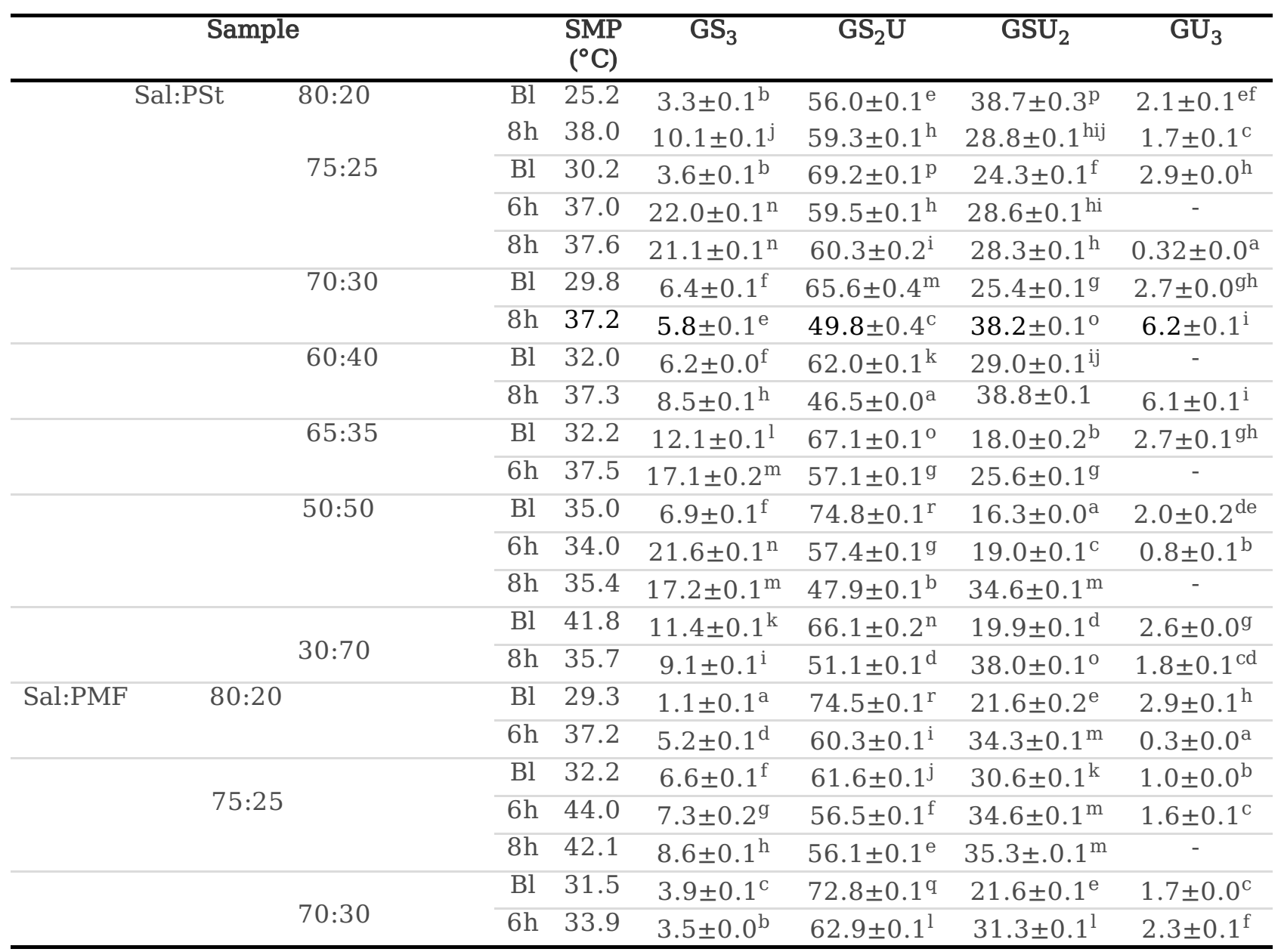

SMP: Slip melting point, PMF: Palm mid-fraction; PSt: palm stearin; Bl: blend; h: hours; $\mathrm{GS}_{3}$ : Trisaturated;

$\mathrm{GS}_{2} \mathrm{U}$ : Di-saturated; $\mathrm{GU}_{2} \mathrm{~S}$ : Di-unsaturated; GU3: Tri-unsaturated glycerides.

Values are mean \pm SD of triplicate values; Values not having similar superscripts in the same column are significantly $(P \leq$ $0.05)$

different.

Table 4 Effect of time on triglyceride composition of sal and palm stearin blends and after interesterification

\begin{tabular}{ccccccc}
\hline Sal:PSt & & $\begin{array}{c}\text { SMP } \\
\left({ }^{\circ} \mathrm{C}\right)\end{array}$ & $\mathrm{GS}_{3}$ & $\mathrm{GS}_{2} \mathrm{U}$ & $\mathrm{GSU}_{2}$ & $\mathrm{GU}_{3}$ \\
\hline \multirow{5}{*}{$85: 15$} & $\mathrm{Bl}$ & 31.5 & $7.8 \pm 0.1^{\mathrm{a}}$ & $72.7 \pm 0.3^{\mathrm{d}}$ & $18.2 \pm 0.1^{\mathrm{a}}$ & $0.6 \pm 0.1^{\mathrm{b}}$ \\
& $2 \mathrm{~h}$ & 38.4 & $7.6 \pm 0.1^{\mathrm{a}}$ & $63.2 \pm 0.1^{\mathrm{b}}$ & $29.1 \pm 0.1^{\mathrm{c}}$ & $0.1 \pm 0.1^{\mathrm{a}}$ \\
& $4 \mathrm{~h}$ & 40.0 & $9.8 \pm 0.1^{\mathrm{c}}$ & $63.9 \pm 0.1^{\mathrm{c}}$ & $26.2 \pm 0.1^{\mathrm{b}}$ & - \\
& $6 \mathrm{~h}$ & 39.2 & $9.9 \pm 0.1^{\mathrm{c}}$ & $63.9 \pm 0.1^{\mathrm{c}}$ & $26.1 \pm 0.1^{\mathrm{b}}$ & - \\
& $8 \mathrm{~h}$ & 40.0 & $9.4 \pm 0.1^{\mathrm{b}}$ & $61.0 \pm 0.1^{\mathrm{a}}$ & $29.5 \pm 0.1^{\mathrm{d}}$ & - \\
\hline $20: 80$ & $\mathrm{Bl}$ & 43.6 & $14.0 \pm 0.2^{\mathrm{e}}$ & $54.5 \pm 0.1^{\mathrm{c}}$ & $28.0 \pm 0.1^{\mathrm{a}}$ & $2.2 \pm 0.1^{\mathrm{b}}$ \\
& $2 \mathrm{~h}$ & 36.8 & $8.2 \pm 0.0^{\mathrm{a}}$ & $54.4 \pm 0.2^{\mathrm{c}}$ & $35.8 \pm 0.3^{\mathrm{cd}}$ & $1.6 \pm 0.1^{\mathrm{a}}$ \\
\hline & $4 \mathrm{~h}$ & 39.8 & $9.7 \pm 0.1^{\mathrm{b}}$ & $51.1 \pm 0.1^{\mathrm{b}}$ & $35.9 \pm 0.1^{\mathrm{d}}$ & $3.3 \pm 0.1^{\mathrm{d}}$ \\
& $6 \mathrm{~h}$ & 37.7 & $10.8 \pm 0.1^{\mathrm{c}}$ & $51.1 \pm 0.1^{\mathrm{b}}$ & $35.3 \pm 0.2^{\mathrm{bc}}$ & $2.8 \pm 0.1^{\mathrm{c}}$ \\
& $8 \mathrm{~h}$ & 40.4 & $11.9 \pm 0.1^{\mathrm{d}}$ & $50.2 \pm 0.1^{\mathrm{a}}$ & $35.0 \pm 0.1^{\mathrm{b}}$ & $2.8 \pm 0.1^{\mathrm{c}}$ \\
\hline
\end{tabular}


SMP: Slip melting point; PSt: Palm stearin; Bl: Blend; h: hours; $\mathrm{GS}_{3}$ : Tri-saturated; $\mathrm{GS}_{2} \mathrm{U}$ : Di-saturated; GU $\mathrm{G}_{2}$ : Diunsaturated;

\section{$\mathrm{GU}_{3}$ : Tri-unsaturated glycerides}

Values are mean \pm SD of triplicate values; Values not having similar superscripts in the same column within the group are significantly $(P \leq 0.05)$ different.

Table 5 Triglyceride composition of sal and different fractions of palm oil to prepare butter like fat

\begin{tabular}{lccccccc}
\hline \multicolumn{2}{c}{ Sample } & & $\begin{array}{c}\text { SMP } \\
\left({ }^{\circ} \mathbf{C}\right)\end{array}$ & $\mathbf{G S}_{3}$ & $\mathrm{GS}_{2} \mathrm{U}$ & $\mathrm{GSU}_{2}$ & $\mathrm{GU}_{3}$ \\
\hline Sal:PSt & $70: 30$ & $\mathrm{Bl}$ & 29.5 & $0.24 \pm 0.0^{\mathrm{a}}$ & $74.2 \pm 0.2^{\mathrm{g}}$ & $23.6 \pm 0.1^{\mathrm{d}}$ & $1.6 \pm 0.0^{\mathrm{ab}}$ \\
& & $6 \mathrm{~h}$ & 35.1 & $4.6 \pm 0.1^{\mathrm{d}}$ & $59.0 \pm 0.1^{\mathrm{a}}$ & $36.4 \pm 0.1^{\mathrm{i}}$ & - \\
& \multirow{2}{*}{$60: 40$} & $\mathrm{Bl}$ & 33.1 & $3.6 \pm 0.1^{\mathrm{b}}$ & $74.1 \pm 0.2^{\mathrm{g}}$ & $20.0 \pm 0.2^{\mathrm{a}}$ & $2.3 \pm 0.1^{\mathrm{c}}$ \\
\cline { 3 - 9 } & & $2 \mathrm{~h}$ & 33.5 & $6.1 \pm 0.1^{\mathrm{d}}$ & $65.6 \pm 0.4^{\mathrm{c}}$ & $25.0 \pm 0.1^{\mathrm{f}}$ & $2.3 \pm 0.0^{\mathrm{c}}$ \\
\hline \multirow{2}{*}{ Sal:PMF } & $75: 25$ & $\mathrm{Bl}$ & 30.0 & $3.6 \pm 0.2^{\mathrm{b}}$ & $72.3 \pm 0.1^{\mathrm{f}}$ & $24.1 \pm 0.4^{\mathrm{e}}$ & - \\
& & $6 \mathrm{~h}$ & 33.8 & $3.2 \pm 0.1^{\mathrm{a}}$ & $62.8 \pm 0.2^{\mathrm{b}}$ & $34.0 \pm 0.1^{\mathrm{h}}$ & - \\
& \multirow{2}{*}{$60: 40$} & $\mathrm{Bl}$ & 32.8 & $4.3 \pm 0.1^{\mathrm{cd}}$ & $74.1 \pm 0.3^{\mathrm{g}}$ & $19.9 \pm 0.1^{\mathrm{a}}$ & $1.7 \pm 0.1^{\mathrm{b}}$ \\
& & $2 \mathrm{~h}$ & 34.0 & $4.0 \pm 0.1^{\mathrm{c}}$ & $67.5 \pm 0.1^{\mathrm{d}}$ & $27.0 \pm 0.2^{\mathrm{g}}$ & $1.5 \pm 0.1^{\mathrm{a}}$ \\
\hline & \multirow{2}{*}{$40: 60$} & $\mathrm{Bl}$ & 32.3 & $4.2 \pm 0.3^{\mathrm{c}}$ & $72.2 \pm 0.1^{\mathrm{f}}$ & $21.3 \pm 0.1^{\mathrm{b}}$ & $2.3 \pm 0.1^{\mathrm{c}}$ \\
\hline & & $2 \mathrm{~h}$ & 31.2 & $6.5 \pm 0.1^{\mathrm{e}}$ & $69.2 \pm 0.2^{\mathrm{e}}$ & $22.7 \pm 0.1^{\mathrm{c}}$ & $1.6 \pm 0.0^{\mathrm{ab}}$ \\
\hline
\end{tabular}

SMP: Slip melting point; PSt: Palm stearin; Bl: Blend; h: hours; $\mathrm{GS}_{3}$ : Tri-saturated; $\mathrm{GS}_{2} \mathrm{U}$ : Di-saturated; GU $\mathrm{S}_{2}$ : Diunsaturated;

$\mathrm{GU}_{3}$ : Tri-unsaturated glycerides

Values are mean \pm SD of triplicate values; Values not having similar superscripts in the same column are significantly $(\mathrm{P} \leq$ $0.05)$ different.

\section{Figures}




\section{a}
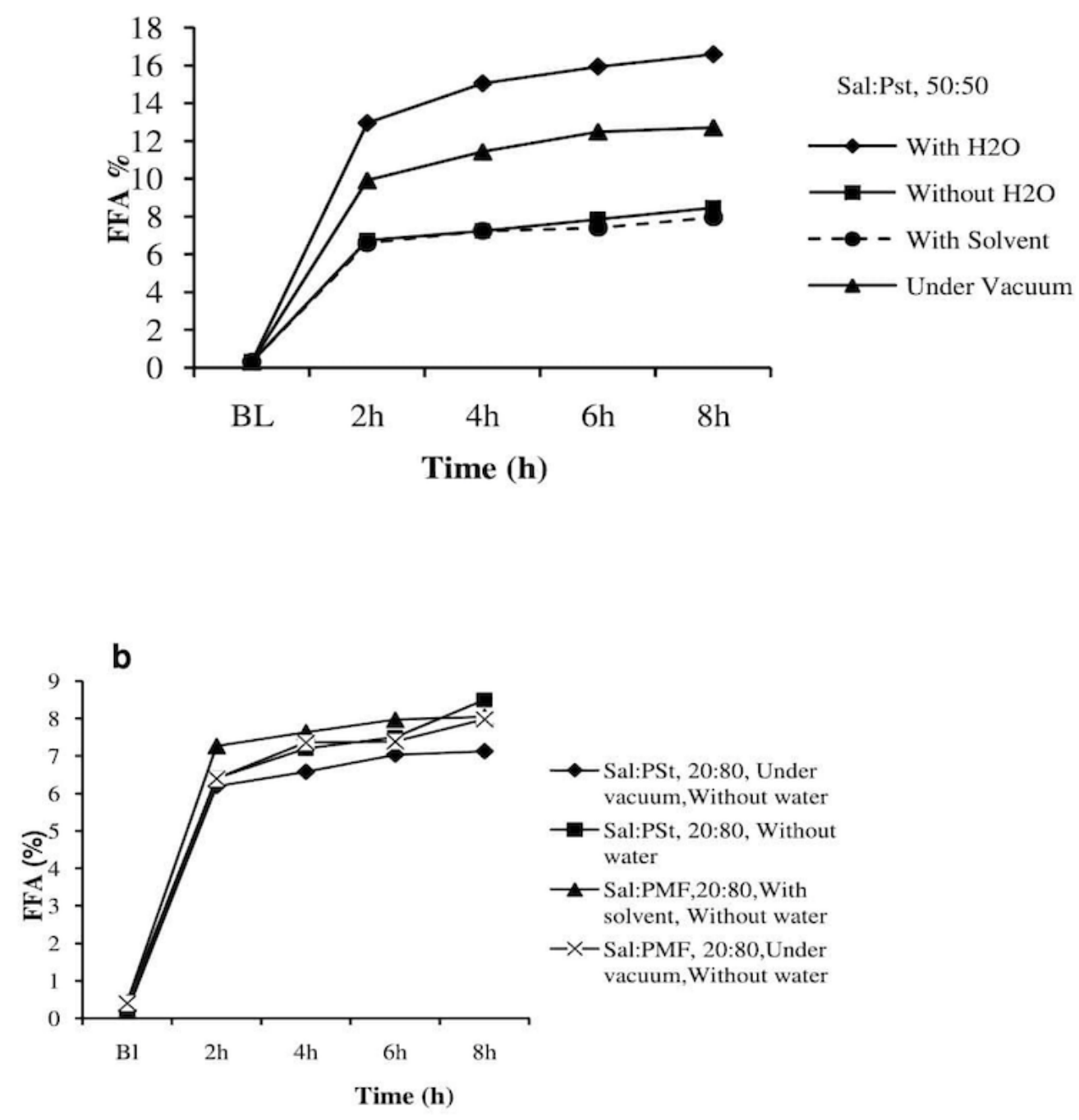

Figure 1

Effect of moisture on FFA content after interesterification at a) different time intervals and b) different conditions in various blends. PSt- Palm stearin, PMF- Palm mid fraction 
a
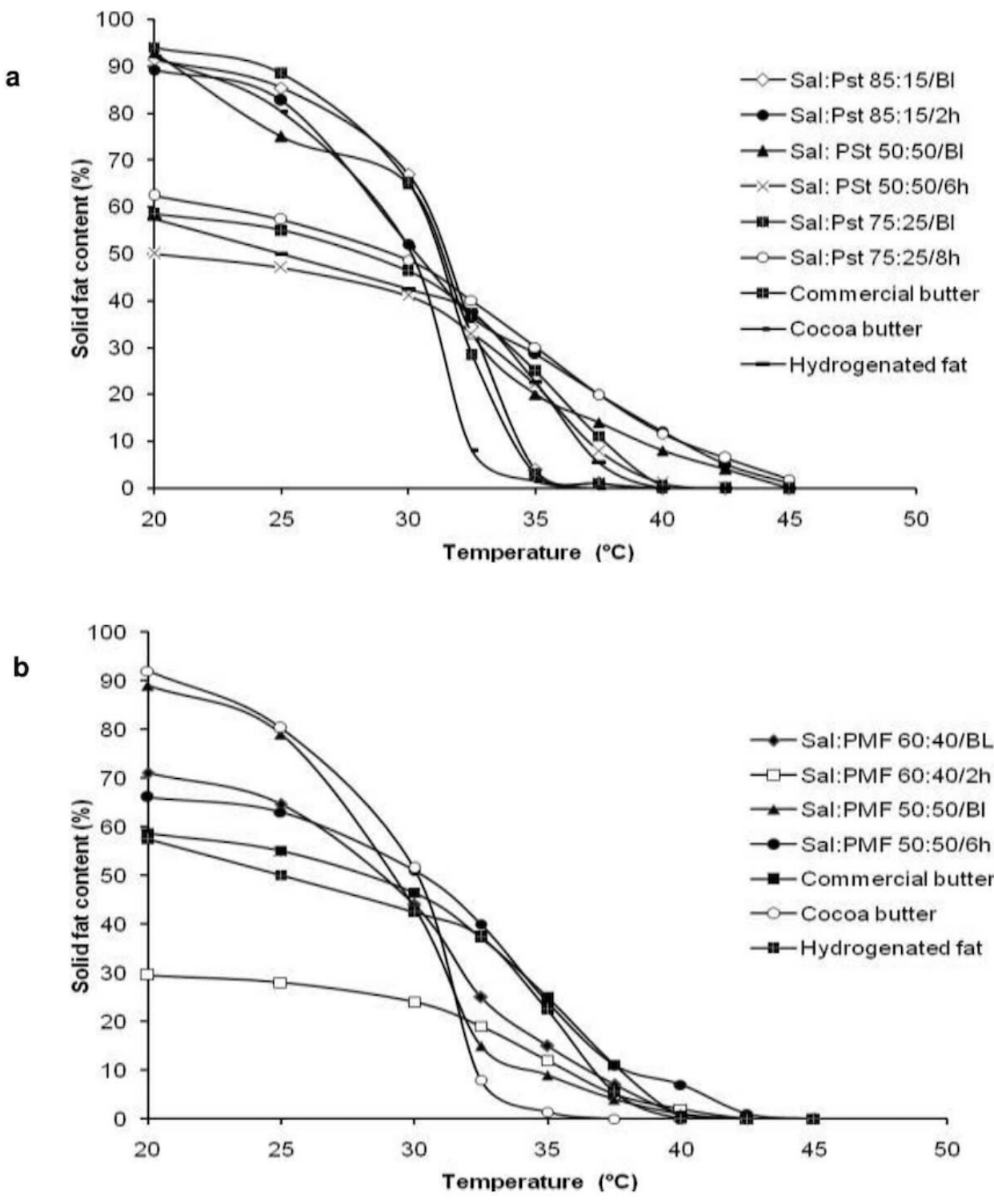

\section{Figure 2}

Solid fat content of a) sal:Pst blends, interesterified and commercial fats b) sal:PMF blends, interesterified and commercial fats. PSt-Palm stearin, PMF- Palm mid fraction, BI- Blend 